\title{
KORELASI DAN ANALISIS LINTAS KARAKTER AGRONOMI KACANG BOGOR (Vigna subterranea L. Verdc.)
}

\author{
Correlation and Path Analysis for Agronomic Traits in Bambara Groundnut \\ (Vigna subterranea L. Verdc.) \\ Yusuf Bachtiar $^{1}$, Yuliawati ${ }^{2}$, Setyono ${ }^{2}$, Arifah Rahayu ${ }^{2}$ \\ ${ }^{1}$ Program Studi Agroteknologi, Fakultas Pertanian, Universitas Djuanda \\ ${ }^{2}$ Staf Pengajar Program Studi Agroteknologi, Fakultas Pertanian, Universitas Djuanda \\ Jalan Tol Ciawi No. 1, Kotak Pos 35 Ciawi Bogor, 16720 \\ *Email : yuliawati@unida.ac.id
}

Diterima 2 Oktober 2020/Disetujui 28 Oktober 2020

\begin{abstract}
ABSTRAK
Upaya perbaikan daya hasil kacang bogor dapat dilakukan melalui program pemuliaan tanaman dan salah satu langkah pentingnya adalah kegiatan seleksi. Seleksi dapat berjalan efektif apabila diketahui keeratan hubungan atau korelasi antara karakter yang dituju dengan karakter lain sebagai penduga. Keeratan hubungan antar karakter komponen hasil dengan karakter hasil kacang bogor dapat diduga menggunakan analisis korelasi dan pengaruh langsung serta pengaruh tidak langsungnya dapat diketahui melalui analisis lintas. Penelitian ini bertujuan untuk mencari komponen penentu daya hasil kacang bogor berdasarkan nilai korelasi, pengaruh langsung, dan pengaruh tidak langsung menggunakan analisis lintas. Penelitian dilaksanakan pada pada Februari-Juni 2018 di kebun percobaan SEAMEO BIOTROP Tajur, Kota Bogor, Jawa Barat ( $\pm 280 \mathrm{~m} \mathrm{dpl}$ ). Rancangan percobaan yang digunakan adalah Rancangan Acak Kelompok (RAK) dengan 31 perlakuan galur lanras asal Sukabumi. Hasil penelitian menunjukkan bahwa karakter agronomi jumlah cabang berkorelasi positif dan nyata terhadap karakter hasil kacang bogor, yaitu bobot polong basah dan bobot polong kering. Karakter agronomi jumlah polong total dan jumlah cabang memiliki pengaruh langsung dan tidak langsung yang besar terhadap bobot polong basah dan bobot polong kering. Sementara itu, karakter jumlah daun, lebar kanopi dan bobot brangkasan basah memberikan pengaruh langsung kecil, tetapi pengaruh tidak langsungnya besar melalui karakter jumlah cabang.
\end{abstract}

Kata kunci: daya hasil, komponen hasil, seleksi

\begin{abstract}
Efforts to improve the yield of Bambara groundnut can be done through plant breeding programs and one of the important steps is selection activities. Selection can run effectively if it is known the closeness of the relationship or correlation between the intended character and other characters as predictors. The closeness of the relationship between the yield component characters and the yielding character of Bambara groundnut can be estimated using correlation analysis and the direct effect and indirect effect can be determined through path analysis. This study aims to find the determining components of the yield of bambara groundnut based on the correlation value, direct effect, and indirect effect using path analysis. The research was conducted in February-June 2018 in the SEAMEO BIOTROP Tajur experimental garden, Bogor City, West Java ( $\pm 280 \mathrm{~m}$ asl). The experimental design used was a randomized
\end{abstract}


complete block design (RCBD) with 31 lines of Sukabumi landrace as a treatment. The results showed that the agronomic character of the number of branches had a positive and significant correlation to the yield characters of bambara groundnut, namely wet pod weight and dry pod weight. The agronomic characters of the total number of pods and the number of branches had a large direct and indirect effect on wet pod weight and dry pod weight. Meanwhile, the character of the number of leaves, the width of the canopy, and the weight of wet stover gave a small direct effect, but the indirect effect was large through the character of the number of branches.

Keywords: selection, yield, yield components

\section{PENDAHULUAN}

Kacang bogor (Vigna subterranea L. Verdc.) merupakan tanaman legum yang berasal dari Afrika tetapi telah lama beradaptasi di Indonesia (Wicaksana et al. 2013). Tanaman legum ini tergolong underutilized crop atau belum banyak dimanfaatkan, padahal memiliki banyak keunggulan dibandingkan tanaman legum lainnya. Keunggulan kacang bogor diantaranya adalah tahan terhadap cekaman lingkungan, seperti stres air dan unsur hara rendah serta memiliki kandungan karbohidrat yang tinggi sehingga dapat dijadikan sebagai sumber pangan alternatif (Azam-Ali et al. 2001). Kandungan karbohidrat pada kacang bogor sebesar $56,51 \%$, kandungan protein 20.,60\%, lemak $6,60 \%$, serat $6,34 \%$, dan abu $3,25 \%$ (Mazahib et al. 2013). Menurut Okpuzor et al. (2010), kacang bogor juga memiliki kandungan lisin $(6,6 \%)$ dan metionin $(1,3 \%)$ yang cukup tinggi. Mineral yang terkandung pada $100 \mathrm{~g}$ biji kacang bogor adalah $59 \mathrm{mg}$ besi, $1240 \mathrm{mg}$ potasium, 296 $\mathrm{mg}$ fosfor, $3,7 \mathrm{mg}$ sodium dan $78 \mathrm{mg}$ kalsium (Amarteifio et al. 2006).

Permasalahan utama dalam produksi kacang bogor adalah daya hasil yang masih rendah. Menurut Massawe et al. (2005), petani kacang bogor masih menggunakan lanras-lanras lokal karena sampai saat ini belum tersedia varietas nasional kacang bogor hasil pemuliaan tanaman. Lanras-lanras lokal tersebut memiliki genotipe yang masih tercampur sehingga produktivitasnya rendah. Hasil evaluasi Adu-Dapaah dan Sangwan (2004) terhadap 23 lanras kacang bogor asal Ghana, menunjukkan bahwa produksi polong keringnya hanya berkisar antara 0,40-1,65 ton ha- ${ }^{-1}$ dengan rata-rata 0,84 ton $\mathrm{ha}^{-1}$. Hasil yang tidak jauh berbeda diperoleh oleh Rahmawati et al. (2016) yang mengevaluasi lanras kacang bogor asal Sumedang pada berbagai jarak tanam. Hasil evaluasi tersebut menunjukkan bahwa produksi polong kering kacang bogor hanya berkisar antara 1,13-2,04 ton $\mathrm{ha}^{-1}$ dengan rata-rata produksi 1,7 ton $\mathrm{ha}^{-1}$. Upaya perbaikan daya hasil kacang bogor dapat dilakukan melalui program pemuliaan tanaman dan salah satu langkah pentingnya adalah kegiatan seleksi. Keberhasilan atau kegagalan suatu program pemuliaan tanaman sangat tergantung pada kemampuan pemulia dalam mengidentifikasi genotipe-genotipe unggul melalui kegiatan seleksi. Seleksi secara langsung terhadap karakter-karakter hasil umumnya tidak efektif karena karakter hasil lebih banyak dipengaruhi oleh lingkungan dibandingkan genetik. Menurut Wardana et al. (2015), seleksi dapat berjalan efektif apabila diketahui keeratan hubungan atau korelasi antara karakter yang dituju dengan karakter lain sebagai penduga. Keeratan hubungan antar karakter komponen hasil dengan karakter hasil kacang bogor dapat diduga menggunakan analisis korelasi dan pengaruh langsung serta pengaruh tidak langsungnya dapat diketahui melalui analisis lintas.

Penelitian ini bertujuan untuk mencari komponen penentu daya hasil 
kacang bogor berdasarkan nilai korelasi, pengaruh langsung, dan pengaruh tidak langsung menggunakan analisis lintas.

\section{BAHAN DAN METODE}

Penelitian dilaksanakan pada pada Februari-Juni 2018 di kebun percobaan SEAMEO BIOTROP Tajur, Kota Bogor, Jawa Barat $( \pm 280 \mathrm{~m}$ dpl$)$. Rancangan percobaan yang digunakan adalah Rancangan Acak Kelompok (RAK) dengan 31 perlakuan galur lanras asal Sukabumi. Setiap galur ditanam dalam satu bedengan dalam kelompok yang sama kemudian diulang sebanyak tiga kali. Satu satuan percobaan berupa satu bedengan tunggal yang terdiri atas 20 tanaman dan sebanyak enam tanaman dipilih sebagai satuan amatan sampel.

Bahan tanaman yang digunakan adalah 30 galur kacang bogor asal lanras Sukabumi hasil seleksi galur murni generasi ke-3 dan pembandingnya adalah kacang bogor asal lanras Sukabumi yang tidak diseleksi. Bahan lain yang digunakan adalah pupuk kandang ayam, pupuk NPK (15-15-15), insektisida berbahan aktif karbofuran deltrametrin dan fungisida berbahan aktif mankozeb $80 \%$. Sementara itu, peralatan yang digunakan adalah alat budidaya, alat tulis, label, kantong plastik bening, kantong jaring (seed bag), seed box, kamera digital, thermohgyrometer dan timbangan analitik.

Percobaan dimulai dengan mengolah lahan dan membagi lahan tersebut menjadi tiga petak besar berukuran masing-masing 4,0 $\mathrm{m} \times 37,2 \mathrm{~m}$ dengan jarak antar petak $\pm 1 \mathrm{~m}$. Pada petak-petak tersebut kemudian dibuat bedenganbedengan kecil sebanyak 31 bedengan per petak besar. Masing-masing benih per galur ditanam dalam dua baris, tiap baris terdiri atas 10 tanaman dengan jarak tanam $60 \mathrm{~cm}$ x $40 \mathrm{~cm}$. Pupuk kandang ayam dengan dosis $10 \mathrm{t} \mathrm{ha}^{-1}$ diaplikasikan seminggu sebelum penanaman pada masing-masing lubang tanam. Penanaman benih kacang bogor dilakukan bersama pemberian pupuk NPK dengan dosis $200 \mathrm{~kg} \mathrm{ha}^{-1}$ dan pemberian insektisida berbahan aktif karbofuran dengan dosis $20 \mathrm{~kg} \mathrm{ha}^{-1}$. Penyulaman dilakukkan pada saat tanaman berumur 14 hari setelah tanam (HST). Pembumbunan dilaksanakan pada 32, 55 dan 80 HST, sementara pengendalian gulma dilakukan setiap dua minggu sekali. Penyemprotan insektisida berbahan aktif deltrametrin dengan dosis $25 \mathrm{~g} \mathrm{~L} \mathrm{~L}^{-1}$ dilakukan pada 30, 46, 61 dan 73 HST. Panen dilaksanakan secara serentak pada umur 112 HST, setelah itu diamati dan dikeringkan di bawah sinar matahari selama \pm 14 hari.

Pengamatan dilakukan pada 6 tanaman contoh tiap satuan percobaan, kecuali pada peubah umur berbunga yang diamati pada seluruh tanaman setiap galur. Peubah yang diamati adalah umur berbunga, tinggi tanaman, jumlah daun, lebar kanopi, jumlah cabang, bobot brangkasan, jumlah polong total, jumlah polong bernas, jumlah polong cipo, bobot polong basah total dan bobot polong kering total $(\mathrm{g})$.

Uji korelasi pada penelitian ini dilakukan untuk mempelajari keeratan hubungan antar satu karakter dengan karakter lainnya. Nilai koefisien korelasi dihitung menggunakan rumus Walpole (1997). Nilai koefisien korelasi hasil perhitungan sebelumnya digunakan dalam perhitungan koefisien lintas dengan menggunakan rumus menurut Singh dan Chaudhary (1979).

\section{HASIL DAN PEMBAHASAN}

\section{Analisis Korelasi}

Analisis korelasi adalah analisis yang digunakan untuk mengukur derajat keeratan hubungan linear antara dua karakter atau lebih (Safitri et al. 2011). Koefisien korelasi memiliki kisaran nilai -1 sampai $1(-1 \leq \mathrm{r} \leq 1)$.

Tabel 1. Korelasi antar karakter agronomi kacang bogor 


\begin{tabular}{|c|c|c|c|c|c|c|c|c|c|c|c|}
\hline Karakter & TT & JD & JC & LK & UB & BBB & JPB & JPC & JPT & BPB & BPK \\
\hline DT & $-0,05$ & $-0,02$ & $-0,10$ & $-0,06$ & $-0,27 *$ & $-0,27 *$ & $-0,31 *$ & $-0,06$ & $-0,23 *$ & $-0,26^{*}$ & $-0,22 *$ \\
\hline TT & & $0,55^{*}$ & $0,52 *$ & $0,47 *$ & $-0,04$ & $0,38^{*}$ & 0,15 & $0,38^{*}$ & $0,21 *$ & $0,29 *$ & $0,37 *$ \\
\hline JD & & & $0,75^{*}$ & $0,66^{*}$ & $-0,10$ & $0,53 *$ & $0,35^{*}$ & $0,59 *$ & $0,49^{*}$ & $0,52 *$ & $0,56^{*}$ \\
\hline $\mathrm{JC}$ & & & & $0,74^{*}$ & $-0,05$ & $0,47 *$ & $0,35^{*}$ & $0,59 *$ & $0,46^{*}$ & $0,63 *$ & $0,67 *$ \\
\hline LK & & & & & 0,00 & $0,59 *$ & $0,39 *$ & $0,52 *$ & $0,46^{*}$ & $0,58 *$ & $0,60 *$ \\
\hline UB & & & & & & 0,10 & 0,10 & 0,00 & 0,08 & 0,06 & $-0,02$ \\
\hline BBB & & & & & & & $0,49 *$ & $0,41 *$ & $0,54^{*}$ & $0,53 *$ & $0,58^{*}$ \\
\hline JPB & & & & & & & & $0,26^{*}$ & $0,94 *$ & $0,62 *$ & $0,68^{*}$ \\
\hline JPC & & & & & & & & & $0,48^{*}$ & $0,41^{*}$ & $0,40 *$ \\
\hline JPT & & & & & & & & & & $0,65 *$ & $0,71 *$ \\
\hline BPB & & & & & & & & & & & $0,89 *$ \\
\hline
\end{tabular}

Keterangan : TT=tinggi tanaman, JD=jumlah daun, JC=jumlah cabang, LK=lebar kanopi, UB=umur berbunga, $\mathrm{BBB}=$ bobot brangkasan basah, $\mathrm{JPB}=$ jumlah polong bernas, JPC=jumlah polong cipo, JPT=jumlah polong total, $\mathrm{BPB}=$ bobot polong basah, $\mathrm{BPK}=$ bobot polong kering, angka yang diikuti tanda * berbeda nyata pada taraf $5 \%$.

Nilai $\mathrm{r}$ mendekati 1 atau -1 mengindikasikan hubungan antara kedua karakter semakin erat, sementara nilai $\mathrm{r}$ yang mendekati 0 menunjukkan tidak terdapat keeratan hubungan antar kedua karakter (Walpole 1997). Hasil analisis korelasi antar karakter agronomi kacang bogor disajikan pada Tabel 1.

Koefisien korelasi antara daya tumbuh dengan semua karakter bernilai negatif dan nyata pada karakter umur berbunga, bobot brangkasan basah, bobot polong basah, bobot polong kering, jumlah polong bernas dan jumlah polong total. Koefisien korelasi yang bernilai negatif menunjukkan bahwa hubungan antar kedua karakter berbanding terbalik yaitu peningkatan nilai suatu karakter akan diikuti penurunan nilai karakter lainnya Akhmadi et al. (2017). Oleh karena itu, peningkatan nilai karakter umur berbunga, bobot brangkasan basah, bobot polong basah, bobot polong kering, jumlah polong bernas dan jumlah polong total secara nyata akan diiringi penurunan daya tumbuh kacang bogor.

Selain karakter daya tumbuh, koefisien korelasi yang bernilai negatif ditemukan pada karkater umur berbunga dengan semua karakter vegetatif, kecuali lebar kanopi yang tidak berkolerasi karena $\mathrm{r}$ bernilai nol. Karakter umur berbunga diharapkan memiliki nilai koefisien korelasi negatif, sehingga dapat diidentifikasi galur-galur kacang bogor berdaya hasil tinggi dan berumur genjah. Umur berbunga kacang bogor dapat dikatakan tidak berkorelasi dengan semua karakter agronomi karena semua nilai koefisiennya mendekati nol, kecuali untuk karakter daya tumbuh.

Semua karakter vegetatif seperti tinggi tanaman, jumlah daun, jumlah cabang dan lebar kanopi saling berkorelasi positif dan nyata pada taraf $5 \%$, kecuali pada karakter daya tumbuh. Nilai koefisien korelasi yang positif menunjukkan bahwa peningkatan suatu karakter akan diikuti oleh peningkatan karakter lainnya (Hapsari 2014). Karakter vegetatif yang memiliki nilai $\mathrm{r}$ paling besar secara berturut-turut adalah jumlah daun dengan jumlah cabang $(r=0,75)$, jumlah cabang dengan lebar kanopi $(r=0,74)$, jumlah daun dengan lebar kanopi $(r=0,66)$, tinggi tanaman dengan jumlah daun $(\mathrm{r}=0,55)$ dan tinggi tanaman dengan jumlah cabang $(r=0,52)$.

Secara keseluruhan nilai koefisien korelasi antara semua karakter hasil berkorelasi positif dan nyata pada taraf $5 \%$. Nilai koefisien korelasi karakter hasil yang paling tinggi yaitu jumlah polong bernas dengan jumlah polong total $(r=0,94)$ dan bobot polong basah dengan bobot polong kering $(r=0,89)$. Bobot brangkasan basah berkorelasi dan nyata terhadap jumlah 
polong cipo, jumlah polong bernas, jumlah polong total, bobot polong basah dan bobot polong kering.

Karakter agronomi tinggi tanaman, jumlah daun, jumlah cabang dan lebar kanopi berkorelasi positif dan nyata (taraf 5\%) terhadap semua karakter hasil, kecuali tinggi tanaman dengan jumlah polong bernas yang memiliki nilai korelasi rendah yaitu 0,15 . Seluruh peubah vegetatif, kecuali daya tumbuh berkorelasi positif dan nyata (taraf 5\%) terhadap karkater hasil kacang bogor, yaitu bobot polong basah dan bobot polong kering. Jumlah cabang memiliki nilai korelasi paling tinggi dibandingkan dengan peubah vegetatif lainnya terhadap peubah bobot polong kering dan bobot polong basah dengan nilai r 0,67 dan 0,63. Hal tersebut sesuai dengan penelitian Nabila (2014), bahwa karakter vegetatif galur-galur kacang bogor saling berkorelasi positif dan nyata terhadap daya hasil kacang bogor kecuali untuk karakter umur berbunga.

\section{Analisis Lintas}

Analisis lintas merupakan metode analisis yang dapat menjelaskan keeratan hubungan antar karakter dengan menguraikan koefisien korelasi menjadi pengaruh langsung dan tidak langsung (Safuan et al. 2014). Maksud dari pengaruh langsung adalah komponen hasil memberikan pengaruh terhadap hasil tanpa melalui perantara komponen hasil lain (Rachmawati et al. 2014). Pengaruh secara tidak langung menurut Chandrasari (2013) adalah komponen hasil memberikan pengaruh terhadap hasil melalui perantara komponen hasil lain. Analisis korelasi hanya memberikan informasi mengenai keeratan hubungan antar dua karakter tetapi tidak menjelaskan sebab akibat, sementara melalui analsis lintas hubungan sebab akibat dapat dijelaskan.

Bobot polong basah dan bobot polong kering merupakan karakter hasil kacang bogor yang digunkan untuk analisis lintas. Analisis lintas untuk bobot polong basah terdiri atas karakter agronomi daya tumbuh, tinggi tanaman, jumlah daun, jumlah cabang, lebar kanopi, umur berbunga, bobot brangkasan basah dan jumlah polong total. Hasil kali dari matriks invers koefisien korelasi delapan karakter agronomi dengan matriks koefisien korelasi bobot polong basah menghasilkan nilai pengaruh langsung. Hasil analisis lintas terhadap bobot polong basah dapat dilihat pada Tabel 2.

Tabel 2. Pengaruh langsung dan tidak langsung beberapa karakter agronomi kacang bogor terhadap bobot polong basah

\begin{tabular}{|c|c|c|c|c|c|c|c|c|c|c|}
\hline \multirow{2}{*}{ Karakter } & \multirow{2}{*}{ PL } & \multicolumn{8}{|c|}{ Pengaruh tidak langsung } & \multirow{2}{*}{ Total } \\
\hline & & DT & TT & JD & $\mathrm{JC}$ & LK & UB & BBB & JPT & \\
\hline DT & $-0,0981$ & - & 0,0025 & 0,0009 & $-0,0377$ & $-0,0083$ & $-0,0029$ & $-0,0250$ & $-0,0880$ & $-0,26$ \\
\hline TT & $-0,0554$ & 0,0045 & - & $-0,0271$ & 0,1896 & 0,0616 & $-0,0004$ & 0,0354 & 0,0778 & 0,29 \\
\hline JD & $-0,0498$ & 0,0017 & $-0,0302$ & - & 0,2756 & 0,0870 & $-0,0010$ & 0,0498 & 0,1844 & 0,52 \\
\hline $\mathbf{J C}$ & 0,3679 & 0,0101 & $-0,0286$ & $-0,0373$ & - & 0,0972 & $-0,0005$ & 0,0440 & 0,1745 & 0,63 \\
\hline LK & 0,1313 & 0,0062 & $-0,0260$ & $-0,0330$ & 0,2724 & - & 0,0000 & 0,0551 & 0,1733 & 0,58 \\
\hline UB & 0,0107 & 0,0263 & 0,0020 & 0,0049 & $-0,0177$ & $-0,0003$ & - & 0,0093 & 0,0296 & 0,06 \\
\hline BBB & 0,0933 & 0,0262 & $-0,0210$ & $-0,0266$ & 0,1735 & 0,0775 & 0,0011 & - & 0,2060 & 0,53 \\
\hline JPT & 0,3785 & 0,0228 & $-0,0114$ & $-0,0242$ & 0,1696 & 0,0601 & 0,0008 & 0,0508 & - & 0,65 \\
\hline Nilai sisaan & $\mathbf{0 , 4 1}$ & & & & & & & & & \\
\hline Cs & 0,64 & & & & & & & & & \\
\hline
\end{tabular}


Berdasarkan Tabel 2, dapat diketahui bahwa karakter jumlah polong total dan jumlah cabang memberikan pengaruh langsung dan tidak paling besar terhadap bobot polong basah dengan nilai pengaruh langsung masing-masing 0,38 dan 0,37 serta pengaruh tidak langsung masing-masing 0,65 dan 0,63. Beberapa karakter memberikan pengaruh langsung kecil terhadap bobot polong basah, seperti umur berbunga, lebar kanopi, bobot brangkasan basah, daya tumbuh, tinggi tanaman dan jumlah daun. Nilai pengaruh karakter-karakter tersebut akan mendekati nol jika dibulatkan yang artinya tidak berpengaruh langsung terhadap bobot polong basah.

Beberapa karakter kacang bogor memberikan pengaruh langsung yang kecil terhadap bobot polong basah, tetapi memberikan pengaruh tidak langsung besar melalui karakter lain. Jumlah daun memberikan pengaruh tidak langsung cukup tinggi melalui karakter jumlah cabang yang memberikan pengaruh sebesar 0,28 . Selain jumlah daun, lebar kanopi juga memberikan pengaruh langsung kecil tetapi pengaruh langsung cukup besar melalui jumlah cabang sebesar 0,27 , serta bobot brangkasan basah melalui jumlah polong total sebesar 0,21.

Uji signifikansi koefisien lintas identik dengan uji signifikansi koefisien persamaan regresi, yaitu keduanya menggunakan statistik uji-t (Kadir 2015). Hasil uji signifikansi koefisien lintas bobot polong basah tersaji pada Tabel 3 .

Tabel 3. Pengujian koefisien lintas pada analisis lintas bobot polong basah

\begin{tabular}{lcccc}
\hline \multicolumn{1}{c}{ Karakter } & Koefisien lintas & Standard error & T hitung & $\boldsymbol{P}$-value \\
\hline DT & $-0,0981$ & 0,0775 & $-1,2655$ & 0,2092 \\
TT & $-0,0554$ & 0,0873 & $-0,6345$ & 0,5275 \\
JD & $-0,0498$ & 0,1201 & $-0,4144$ & 0,6796 \\
JC & 0,3679 & 0,1253 & $2,9358^{*}$ & 0,0043 \\
LK & 0,1313 & 0,1166 & 1,1256 & 0,2635 \\
P50 & 0,0107 & 0,0739 & 0,1442 & 0,8857 \\
BBB & 0,0933 & 0,0998 & 0,9344 & 0,3528 \\
JPT & 0,3785 & 0,0903 & $4,1902^{*}$ & 0,0001 \\
\hline
\end{tabular}

Keterangan : *nyata pada $\alpha=5 \%$, DT=daya tumbuh, TT=tinggi tanaman, JD=jumlah daun, JC=jumlah cabang, $\mathrm{LK}=$ lebar kanopi, $\mathrm{UB}=$ umur berbunga, $\mathrm{BBB}=$ bobot brangkasan basah, JPB=jumlah polong bernas, $\mathrm{JPC}=$ jumlah polong cipo, JPT=jumlah polong total

Hasil pengujian koefisien lintas menunjukkan bahwa hanya pengaruh langsung jumlah cabang dan jumlah polong total yang nyata terhadap bobot polong basah. Pengaruh langsung yang nyata adalah koefisien lintas yang memiliki thitung lebih besar dari t-tabel pada taraf nyata $5 \%$ (Gambar 1).
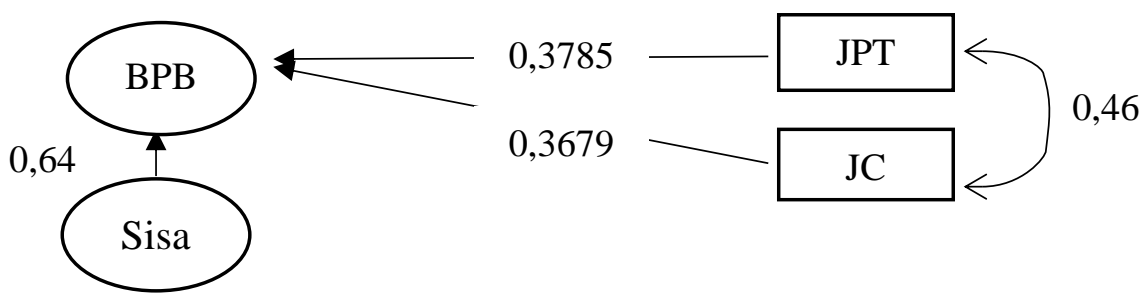

Gambar 1. Diagram lintas untuk bobot polong basah (model akhir) 
Model diagram lintasan bobot polong basah yang dilengkapi dengan koefisien lintas dan koefisien sisaan tertera pada Gambar 1. Nilai sisaan pada model ini adalah 0,41 yang berarti bahwa model analisis lintas tidak dapat menjelaskan keragaman total dari karakter bobot polong basah sebesar $41 \%$.

Analisis lintas untuk bobot polong kering terdiri atas karakter agronomi daya tumbuh, tinggi tanaman, jumlah daun, jumlah cabang, lebar kanopi, umur berbunga, bobot brangkasan basah dan jumlah polong total. Hasil kali dari matriks invers koefisien korelasi delapan karakter agronomi dengan matriks nilai koefisien korelasi bobot polong kering menghasilkan nilai pengaruh langsung. Hasil analisis lintas terhadap bobot polong kering dapat dilihat pada Tabel 4.

Tabel 4. Pengaruh langsung dan tidak langsung beberapa karakter agronomi kacang bogor terhadap bobot polong kering

\begin{tabular}{|c|c|c|c|c|c|c|c|c|c|c|}
\hline \multirow{2}{*}{ Karakter } & \multirow{2}{*}{ PL } & \multicolumn{8}{|c|}{ Pengaruh tidak langsung } & \multirow{2}{*}{ Total } \\
\hline & & DT & TT & JD & $\mathrm{JC}$ & LK & UB & BBB & JPT & \\
\hline DT & $-0,0476$ & - & $-0,0017$ & 0,0018 & $-0,0420$ & $-0,0028$ & 0,0193 & $-0,0387$ & $-0,1067$ & $-0,22$ \\
\hline TT & 0,0369 & 0,0022 & - & $-0,0553$ & 0,2110 & 0,0210 & 0,0026 & 0,0549 & 0,0943 & 0,37 \\
\hline JD & $-0,1014$ & 0,0008 & 0,0201 & - & 0,3068 & 0,0297 & 0,0070 & 0,0771 & 0,2235 & 0,56 \\
\hline JC & 0,4094 & 0,0049 & 0,0190 & $-0,0760$ & - & 0,0332 & 0,0035 & 0,0681 & 0,2115 & 0,67 \\
\hline LK & 0,0448 & 0,0030 & 0,0173 & $-0,0672$ & 0,3032 & - & 0,0002 & 0,0853 & 0,2100 & 0,60 \\
\hline UB & $-0,0719$ & 0,0127 & $-0,0013$ & 0,0099 & $-0,0197$ & $-0,0001$ & - & 0,0144 & 0,0359 & $-0,02$ \\
\hline BBB & 0,1445 & 0,0127 & 0,0140 & $-0,0541$ & 0,1930 & 0,0265 & $-0,0072$ & - & 0,2497 & 0,58 \\
\hline JPT & 0,4589 & 0,0111 & 0,0076 & $-0,0494$ & 0,1887 & 0,0205 & $-0,0056$ & 0,0786 & - & 0,71 \\
\hline Nilai sisaan & \multicolumn{2}{|c|}{$\mathbf{0 , 3 2}$} & & & & & & & & \\
\hline Cs & \multicolumn{2}{|c|}{0,56} & & & & & & & & \\
\hline
\end{tabular}

Keterangan : $\mathrm{PL}=$ pengaruh langsung, TT=tinggi tanaman, JD=jumlah daun, JC=jumlah cabang, LK=lebar kanopi, UB=umur berbunga, $\mathrm{BBB}=$ bobot brangkasan basah, JPB=jumlah polong bernas, $\mathrm{JPC}=$ jumlah polong cipo, $\mathrm{JPT}=$ jumlah polong total

Hasil analisis lintas beberapa karakter agronomi terhadap bobot polong kering memberikan hasil yang tidak jauh berbeda dengan analisis lintas terhadap bobot polong basah. Jumlah polong total dan jumlah cabang memerikan baik pengaruh lagsung maupun pengaruh tidak langsung paling besar terhadap bobot polong kering dengan nilai pengaruh langsung masing-masing 0,46 dan 0,41 serta pengaruh tidak langsung masingmasing 0,71 dan 0,67. Pada tabel terlihat pula bahwa karakter jumlah daun, lebar kanopi dan bobot brangkasan basah memiliki pengaruh langsung kecil tetapi pengaruh tidak langsungnya besar karena pengaruh jumlah cabang dan jumlah polong total.
Jumlah cabang memberikan pengaruh langsung dan tidak langsung yang tinggi hampir pada semua karakter, terutama jumlah daun. Selain itu, jumlah cabang memiliki nilai koefisien korelasi yang positif dan nyata, sehingga peningkatan jumlah cabang akan nyata dikuti oleh peningkatan jumlah daun. Jumlah daun yang meningkat akan menyebabkan terjadinya peningkatan laju fotosintesis karena semakin banyak cahaya yang ditangkap oleh tanaman (Buntoro et el. 2014). Menurut Repkova et al. (2009), penigkatan laju fotosistesis akan mendorong peningkatan biomassa, hasil dan kualitas tanaman kacang bogor.

Hasil uji signifikansi koefisien lintas bobot polong kering tersaji pada Tabel 5. 
Tabel 5. Pengujian koefisien lintas pada analisis lintas bobot polong kering

\begin{tabular}{|c|c|c|c|c|}
\hline Karkater & Koefisien lintas & Standard error & T hitung & P-value \\
\hline DT & $-0,0476$ & 0,0680 & $-0,6996$ & 0,4861 \\
\hline $\mathrm{TT}$ & 0,0369 & 0,0766 & 0,4817 & 0,6313 \\
\hline JD & $-0,1014$ & 0,1054 & $-0,9617$ & 0,3390 \\
\hline $\mathrm{JC}$ & 0,4094 & 0,1100 & $3,7227 *$ & 0,0004 \\
\hline LK & 0,0448 & 0,1023 & 0,4380 & 0,6625 \\
\hline P50 & $-0,0719$ & 0,0649 & $-1,1085$ & 0,2708 \\
\hline BBB & 0,1445 & 0,0876 & 1,6491 & 0,1029 \\
\hline JPT & 0,4589 & 0,0793 & $5,7876^{*}$ & 0,0000 \\
\hline
\end{tabular}

Keterangan : *nyata pada $\alpha=5 \%$, DT=daya tumbuh, TT=tinggi tanaman, JD=jumlah daun, JC=jumlah cabang, $\mathrm{LK}=$ lebar kanopi, UB=umur berbunga, $\mathrm{BBB}=$ bobot brangkasan basah, JPB=jumlah polong bernas, $\mathrm{JPC}=$ jumlah polong cipo, JPT=jumlah polong total

Hasil pengujian koefisien lintas menunjukkan bahwa hanya pengaruh langsung jumlah cabang dan jumlah polong total yang nyata terhadap bobot polong

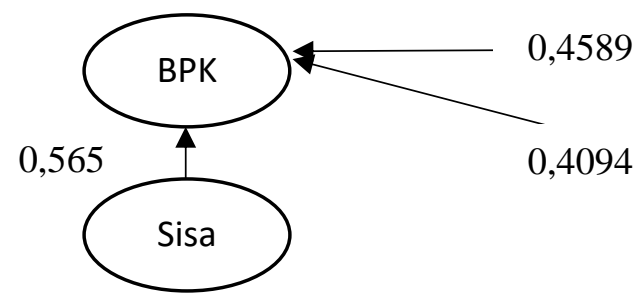

kering (Tabel 5). Pengaruh langsung yang nyata adalah koefisien lintas yang memiliki t-hitung lebih besar dari t-tabel pada taraf nyata $5 \%$.

Gambar 2. Diagram lintas untuk bobot polong kering (model akhir)

Model diagram lintasan bobot polong kering yang dilengkapi dengan koefisien lintas dan koefisien sisaan tertera pada Gambar 2. Nilai sisaan pada model ini adalah 0,32 yang berarti bahwa analisis lintas tidak dapat menjelaskan keragaman total dari karakter bobot polong kering sebesar $32 \%$.

\section{KESIMPULAN}

Karakter agronomi jumlah cabang berkorelasi positif dan nyata terhadap karakter daya hasil kacang bogor, yaitu bobot polong basah dan bobot polong kering. Karakter agronomi jumlah polong total dan jumlah cabang memiliki pengaruh langsung dan tidak langsung yang besar terhadap bobot polong basah dan bobot polong kering. Sementara itu, karakter jumlah daun, lebar kanopi dan bobot brangkasan basah memberikan pengaruh langsung kecil, tetapi pengaruh tidak langsungnya besar melalui karakter jumlah cabang.

\section{DAFTAR PUSTAKA}

Adu-Dapaah HK, Sangwan RS. 2004. Improving bambara groundnut productivity using gamma irradiation and in vitro techniques. Afrc $\mathbf{J}$ Biotech. 3(5):260-265.

Akhmadi G, Purwoko BS, Dewi IS, Wirnas D. 2017. Karakter agronomi untuk seleksi pada galur-galur padi dihaploid hasil kultur antera. J Agron Indo. 45(1):1-8.

Amarteifio JO, Tibe O, Njogu RM. 2006. The mineral composition of bambara groundnut (Vigna subterranea (L) Verdc) grown in Southern Africa. Afr J Bio. 5(23):2408-2411. 
Azam-Ali SN, Sesay A, Karikari KS, Massawe FJ, Aguilar-Manjarrez J, Bannayan M, Hampson KJ. 2001. Assessing the potential of an underutilized crop-a case study using bambara groundnut. Exp Agric. 37(4):33-72.

Buntoro BH, Rogomulyo R, Trisnowati S. 2014. Pengaruh takaran pupuk kandang dan intensitas cahaya terhadap pertumbuhan dan hasil temu putih (Curcuma zedoaria L.). Vegetika. 3(4):29-39.

Chandrasari, Suciati E, Nasrullah, Sutardi. 2013. Uji daya hasil delapan galur harapan padi sawah. Vegetalika. 1(2):99-107.

Hapsari RT. 2014. Pendugaan keragaman genetik dan korelasi antara komponen hasil kacang hijau berumur genjah. Buletin Plasma Nutfah. 20(2):51-58.

Kadir. 2015. Statistika Terapan : Konsep, Contoh dan Analisis Data dengan Program SPSS/Liseral dalam Penelitian. Jakarta : Rajawali Pers.

Massawe FJ, Mwale SS, Azam-Ali SN, Roberts JA. 2005. Breeding in bambara groundnut (Vigna subterranea L. Verdc.) : strategic considerations. Afr $J$ Biotec. 4(6):463-471.

Mazahib AM, Nuha MO, Salawa IS, Babiker EE. 2013. Some nutritional attributes of bambara groundnut as influenced by domestic processing. Inter Food Res J. 20(3):1165-1171.

Nabila N. 2014. Seleksi galur murni lanras kacang bogor (Vigna subterranea L.) asal Sukabumi [skripsi]. Bogor [ID] : Institut Pertanian Bogor.

Okpuzor J, Ogbunugafor HA, Okafor U, Sofidiya MO. 2010. Identification of protein types in bambara nut seeds: perspectives for dietary protein supply in developing countries. EXCLI J. 9:17-28.

Rachmawati RY, Kuswanto, Purnamaningsih SL. 2014. Uji keseragaman dan analisis sidik lintas antara karakter agronomis dengan hasil pada tujuh genotip padi hibrida Japonica. J Prod Tan. 2(4):292-300.

Rahmawati A, Purnamawati H, Kusumo YWE. 2016. Pertumbuhan dan produksi kacang bogor (Vigna subterranea (L.) Verdcourt) pada beberapa jarak tanam dan frekuensi pertumbuhan. Bul Agro. 4(3):302311.

Repkova J, Brestic M, Olsovska K. 2009. Leaf growth under temperature and light control. Plant Soil Env J. 55(12):551-557.

Safitri H, Purwoko BS, Dewi IS, Abdullah B. 2011. Korelasi dan sidik lintas karakter fenotipik galur-galur padi haploid ganda hasil kultur antera. Widyariset. 14(2):295-304.

Safuan LO, Boer D, Wijayanto T, Susanti N. 2014. Analisis koefisien lintas berbagai sifat agronomi yang mempengaruhi hasil kultivar jagung pulut (Zea mays Ceritina Kulesh) lokal Sulawesi Tenggara. AGRIPLUS. 24(02):136-143.

Singh RK, Chaudhary BD. 1979. Biometrical Methods in Quantitative Genetic Analysis. New Delhi (IN): Kalyani Publ.

Walpole RE. 1997. Pengantar Statistika Edisi ke-3. Bambang S, penerjemah. Jakarta (ID): Gramedia pustaka utama. Terjemahan dari: Introduction to Statistics $3^{\text {rd }}$ Edition.

Wardana CK, Karyawati AS, Sitompul SM. 2015. Keragaman hasil, heritabilitas dan korelasi f3 hasil persilangan kedelai (Glycine $\max$ L. Merril) varietas Anjasmoro dengan varietas Tanggamus, Grobogan, galur AP dan UB. Jurnal Produksi Tanaman. 3(3):182-188.

Wicaksana N, Hindun, Waluyo B, Rachmadi M, Kurniawan A, Kurniawan H. 2013. Karakterisasi morfo-agronomis kacang bambara (Vigna subterranea L. Verdc.) Asal Jawa Barat. Di dalam : Wicaksana N, Kurniawan A, Waluyo B, Kurniawan 
$\mathrm{H}$, editor. Peran Nyata Hortikultura, Agronomi dan Pemuliaan Terhadap Ketahanan Pangan. Seminar Nasional 3 in ONE Hortikultura, Agronomi dan Pemuliaan Tanaman; 2013 Agust 21; Malang, Indonesia. Malang (ID) : Fakultas Pertanian, Universitas Brawijaya. hlm 349-357. 